\title{
ECONOMICS OF SOYBEAN PRODUCTION TECHNOLOGY IN THE GUINEA SAVANNA OF NIGERIA
}

\author{
Fatoba I. O. *, Omotesho, O. A.**, and Adewumi, M. 0.** \\ *National Cereals Research Institute, Badeggi, Nigeria. \\ ${ }^{* *}$ Department of Agricultural Economics and Farm Management, University of Ilorin, Nigeria.
}

\begin{abstract}
This study examined the economics of soybean production technology in the Guinea Savanna of Nigeria within the framework of small scale farming households using rain-fed soybean production technology, The study measured the rate of compliance with the recommended package, profitability of, as well as the technical efficiency of the production technology. Primary data were collected from one hundred and fifty soybean farming households using structured questionnaire. Descriptive and inferential statistics were used to analyze the data. A Cobb Douglas production function was further employed to analyze the data using the Maximum Likelihood Estimation (MLE) procedure to derive the Stochastic Frontier Production Function.

The study revealed that the typical farming household using the technology had an average farm size of 1.2ha. Further analysis of level of technology compliance revealed a $60 \%$ level with a yield gap of $43 \%$. The farm budget analysis showed that the farming households had positive net farm income using the technology. The MLE of the stochastic frontier function revealed the presence of increasing returns to scale for the production technology. It further revealed a mean output-oriented technical efficiency of 0.75 with possible room for improvement. The estimated parameters of labour, farm size and level of compliance included in the production equation had expected positive signs and are significant at $5 \%$ level.

While the present level of compliance with recommended production package affords the farming households positive gross margins, they are yet to attain their potential yields. In order to move closer to this potential, the present soybean production technology need to be revaluated for improvement and better efficiency. This should include modifications that fulfill the low-cost input desires of the small-scale farming households.
\end{abstract}

KEYWORDS: Production technology, technology compliance, yield gap, technical efficiency

\section{INTRODUCTION}

The agricultural sector of the Nigerian economy holds the key to rapid economic transformation, poverty alleviation, stable democracy and good governance The sector contributes $41 \%$ of the Gross Domestic Product (GDP), 88 percent of the non-oil foreign exchange earnings; 
employs 70 percent of the active labour forces (Federal office of statistics, 1998) as well provide raw materials for the agro-industrial sector.

Soybean is one of the most important food crops presently available from nature's vast but dwindling fauna of potentially edible plant species. Its utility as food and ingredient for modern food manufacture has grown rapidly in Nigeria over the last fifty years. Nigeria is the leading producer of the crop in West and Central Africa ( Root et. al 1987). Introduced into Nigeria in 1908, the country produced 57,000 to 70,000 metric tonnes in the 1961 to 1963 period. There was a decline in production up to the 1970 period owing to the Nigerian Civil War. Production rose from 150,000 metric tonnes in 1988 to 300,000 metric tonnes in 1989 with production reaching 440,000 metric tonnes in 2002, as a result of industrial and domestic use (Iwe, 2003).

Soybean is highly nutritious, containing $40 \%$ protein and $20 \%$ oil. The oil has a high proportion of unsaturated fatty acid and hence very useful in primary health care delivery especially in a developing country like Nigeria. The crop is presently utilized into various products by about twelve agro-allied industries in Nigeria that fully utilize all the nation's productions. Industrial consumption now competes with small-scale rural processors who process the crop. It is estimated that about 10,000 Nigerians are employed in the soya-based industrial sector, while 200,000 rural entrepreneurs process the crop into various products for the local market (Okoruwa 1999; Iwe 2003).

The importance attached to this crop has led to efforts by Research Institutes to develop appropriate technologies for its cultivation by small scale farmers in Nigeria. However, despite the release of soyabean production technology which is expected to help the farmer increase his yield substantially, the overall impact of this technology on production has been marginal. The reasons for this, may be due to the fact that majority of farmers do not adopt all the components of a technology (Okali et. al., 1994; Hildebrand and Russel, 1998; Zeller, 1998). Also, compliance by users of technologies presupposes that such technologies are not only adaptable but affordable. Adaptability presupposes that the technologies can fit into the farmers farming practices while affordability connotes the ability of the farmer to acquire the inputs needed to use the technology as prescribed.

This study therefore evaluates the rain-fed soyabean production technology in Benue state of Nigeria. The study specifically measured the level of compliance of farming households using rainfed soyabean production technology, determined the profitability of the production technology, measure the resource use efficiency of the production technology and highlight the policy implications of our findings.

\section{MATERIALS AND METHOD.}

The study was conducted in Benue State of Nigeria. Benue State is one of the twelve states created in 1976. The State is located between longitude $6^{\circ} 10^{\circ}$ East and Latitude $6^{0} 8^{0}$ North. The State is divided into three agricultural zones, viz: Northern, Eastern and Central zones. The Northern Zone of the ADP zones was purposively selected for this study. This is because the cultivation of soybean is widespread in this zone, with the zone accounting for $92 \%$ of the state's 
soybean output, all of which is produced under rain-fed conditions (FMARD, 2004). This zone lies in the Guinea savannah belt. It is traversed by the Benue and Katsina-Ala Rivers and has a humid climate with mean annual precipitation ranging between 790 to $1012 \mathrm{~mm}$. The average number of rainy days ranges from 190 to 223 days. The rains start in early April and end in October with a peak in August. The dry season lasts for about five months of the year from November to April. The average minimum temperature is about 28 degrees Celsius. The zone has more of forest vegetation than derived savannah and hence its vegetation and soil favour the cultivation of an array of crops.

Ten villages were randomly selected from the existing village listings of the ADP in the zone. Fifteen households were thereafter randomly selected from the villages. Farm level interactive survey sessions provided the basic primary quantitative and qualitative data. Crosssectional data from 150 farming household heads were collected with the aid of pre-tested, structured interview schedules administered by trained enumerators. The secondary data were obtained from the records of Benue State ADPs and their parent ministries of Agriculture, the soybean research programme of NCRI Badeggi, the Central Bank of Nigeria, (CBN) Federal Office of Statistics (FOS), the Federal Department of Agricultural Sciences and the Federal Department of Agriculture. Data collected include components of rainfed soybean production technology, family demographic characteristics, and input and output characteristics of the farm. The survey was conducted in October 2010

\section{Analytical Tools}

\section{Farm Budget Analysis.}

A combination of analytical tools including descriptive, statistical and econometric procedures was utilized to achieve the stated objectives. The farm budget analysis was then employed to determine the costs and returns to the technology. The procedures followed were:

TR-TVC $=\mathrm{GM}$.

Where

$T R=$ Total Revenue

TVC $=$ Total Variable Cost

$\mathrm{GM}=$ Gross Margin

The total value of output for the technology was compared with the expected standard as stipulated by NCRI.

The multiple regression model based on stochastic parametric form was used to measure resource use efficiency/inefficiency, productivity of resource and the indices of input management by household heads in the study area. A stochastic production function assumes the presence of technical inefficiency of production.

Consider stochastic production frontier as:

$$
\operatorname{Ln} Q_{i}=a_{0}+a_{1} \operatorname{Ln} X_{i i}+V_{i} U_{i}
$$


Where $Q_{i}=$ crop output for each technology measured in kilograms

$X_{i}=$ Fertilizer in $(\mathrm{kg})$

$\mathrm{X}_{2}=$ Farm size in (ha)

$\mathrm{X}_{3}=$ Labour in (md)

$X_{4}=$ Use of Improved seed which is a dummy; use $\sim 1$, zero otherwise

$V_{i} \quad$ is assumed to be independent and identically distributed .

$U_{i} \quad$ are the non-negative technical inefficiency effects assumed to be independently distributed and arise from the truncation (at zero) of the normal distribution with variance ó $u^{2}$.

Measurement of farm level efficiency; e", requires first the estimation of the non-negative error $U$, i.e., decomposition of $E$ into its two individual components, $U$ and $V$. the technique of decomposition as suggested by Jondrow et al (1982) involves the conditional distribution of $U$ given e expressed as

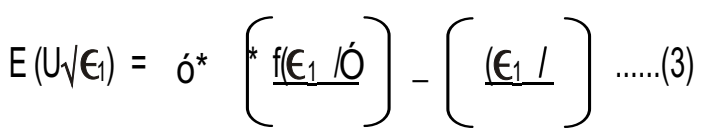

Where $0^{*}=O_{U=0} \dot{O}_{V} \operatorname{oorg}()-U=.Q-u$

$\underline{\epsilon_{1}}=U+V$

$=$ standard deviation of the error term

$\lambda=$ óuór

$f()=$. the standard normal density function (PDF)

$F()=$. the standard distribution function (CDF)

The population average technical efficiency is given as:

$\mathrm{E}\left(\mathrm{e}^{-11}=2^{\mathrm{e} \dot{\mathrm{e} Z u / 2}}\left\{1 \mathrm{~F}\left(\dot{o}^{\mathrm{u}}\right)\right\}\right.$

Where $\mathrm{F}$ is the standard normal distribution function. It should be noted that by taking the natural logarithm of $-u$, the farm specific resource use efficiency index is measured and I - $e^{-u}$ will give resource use inefficiency.

\section{RESULTS AND DISCUSSION}

The mean age of the household head in the study area is 39.6 years with an average of 16 years farming experience. The average physical household size is 7 members per household.

The farm characteristics in terms of physical inputs used during the cropping season are further 
described in Table 2. In computing the labour outlay, a woman day (wd) and child day (cd) were assumed to be 0.75 and 0.50 of a man-day (md) respectively (Norman, 1973).

Table 1:Labour Input Utilization per Hectare using Rainfed Soybean Production Technology.

\begin{tabular}{|c|c|c|c|c|}
\hline \multirow[b]{2}{*}{ Farm operations } & \multicolumn{3}{|c|}{ Sources of Labour (Manday) } & \multirow[t]{2}{*}{ Percentage } \\
\hline & Family & Hired & Total & \\
\hline Land preparation & 10.84 & 6.26 & 17.10 & 21.61 \\
\hline Planting & 7.18 & 5.48 & 12.66 & 16.0 \\
\hline Agronomic operations & 15.84 & 10.08 & 25.92 & 32.75 \\
\hline Harvesting & 7.78 & 2.88 & 10.66 & 13.47 \\
\hline Post harvest operation & 7.66 & 5.14 & 12.80 & 16.17 \\
\hline Total & $49.3(62.3)$ & $29.84(37.7)$ & 79.14 & 100.00 \\
\hline
\end{tabular}

Source: Field Survey 2010

As revealed in Table 1, about 62 percent of total labour used was from family labour while about a third of all operations were used for agronomic operations. With most farm operations executed using the hoe-cutlass technology, farmers can only prepare their farms once during the growing season and this happens as soon as the rains start to ensure maximum use of precipitation required for their crop cycle. As Table 1 revealed, the farming household heads utilize a lot of family labour to supplement available hired labour.

Almost all the farming households in the area planted soybean as sole. As sole cropping is one of the recommendations required for the realization of the full potential of the production technology, the revelation of the cropping pattern presents a good opportunity for the use of the technology. The average farm size is 1.20 ha indicating the small holder nature of farming in the study area. 
Table 2: Description of Farm Inputs Characteristics

\begin{tabular}{lccccc}
\hline Description & $\begin{array}{c}\text { Sample } \\
\text { mean }\end{array}$ & $\begin{array}{c}\text { Standard } \\
\text { deviation }\end{array}$ & $\begin{array}{c}\text { Minimum } \\
\text { value }\end{array}$ & $\begin{array}{c}\text { Maximum } \\
\text { value }\end{array}$ & $\begin{array}{c}\text { Coeff of } \\
\text { variation } \\
(\%)\end{array}$ \\
\hline Farm size (ha) & 1.2 & 0.98 & 0.6 & 6.0 & 85.0 \\
Family labour (MD) & 10.9 & 9.48 & 18.0 & 116 & 87.0 \\
Flired labour (MD) & 6.92 & 5.78 & 29 & 86 & 83.53 \\
Hire labour (N:K) & 2.076 & $1,734.0$ & 8,700 & 25,800 & 83.53 \\
Total labour (N: K) & 5.346 & $5,578.0$ & 14,100 & 60,600 & 85.63 \\
Capital (N:K) & $6,480.0$ & $5,260.0$ & 1,320 & $22,486.0$ & 81.17 \\
Other operating & $4,860.28$ & 2,724 & $10,650.0$ & $26,460.0$ & 56.05 \\
Total cost (\$4) & $\mathbf{1 6 , 7 3 6 . 2 8}$ & $\mathbf{1 2 , 5 6 2}$ & $\mathbf{2 6 , 0 7 0}$ & $\mathbf{1 0 9 , 5 4 6}$ & $\mathbf{7 5 . 0 6}$ \\
\hline
\end{tabular}

(In the study area, the cost per man-day was N300.00)

Source: Field Survey, 2010

Table 2 reveals that, on the average, the cost of hired labour added to the imputed cost of family labour constitute about 32.0 percent while capital costs constitute about 39 percent and operating cost is 29 percent. This scenario clearly indicates that labour is an important factor of production and that farming activities in the area are mostly labour intensive. These findings agree with those of Falusi (1995) and Idachaba (1995) that labour is the most important single factor in Nigerian agriculture.

Farm-level income is defined as the family's owned resources, encompassing family and hired labour, owned and rented land, capital and other farm budgetary technique which is normally considered as the sum of the gross values of outputs produced during the cropping year less all the total costs on the same outputs during the same year. The analysis was done by considering the technology under study. 
Table 3: Distribution of Farm Revenue In the study area

\section{RPT (Soybean)}

$\begin{array}{ll} & 28,866.16 \\ \text { Mean Value of Output (N:K) } & 1.20 \\ \text { Mean farm size (ha.) } & 16,736.28 \\ \text { Means Variable costs (N:K) } & 1.72 \\ \text { Output/Input Value } & 12,129.88 \\ \text { Gross margin (N:K) } & 10,180.23 \\ \text { Gross margin/ha (N:K) } & 120,000 \\ \text { Expected gross margin/ha* } & 1.47 \\ \text { Return to capital } & \\ \end{array}$

*Expected Gross Margin under NCRI On-Station Trial

Source: Field Survey 2010.

The farm revenue analysis is shown on Table 3. It reveals that rainfed soyabean production technology gives a NI0,180.00 gross margin per hectare. Given the fact that the farming households complied with the technology recommendations at $43 \%$ level, the gross margin recorded reflected noncompliance with the stipulates of the technology. However the output/input values of 1.72 indicate that the financial return per unit capital for the technology is positive and encouraging. Without prejudging the other extant parameters, the value of the returns to capital indicates profitability over one cycle-as its value is greater than 1 , indicating that they are financially sustainable. These results, impressive as it may look still do not meet the potential output and output values of the stipulated returns to the production technology and does not fulfill the farming households' goal of optimum income generation.

\section{Analysis of the Stochastic Frontier Estimation.}

Table 4 shows the likelihood parameters of the stochastic production frontier for the production technology in the study area. The variance parameter represented by sigma squared $\left({ }^{2}\right)$ is significant at $5 \%$ and positive. This indicates the goodness of fit and correctness of the specified distributional assumptions of the composite error term. 
Fatoba, Omotesho and Adewumi

Table 4: MLE Estimates of the Stochastic and Efficiency Inefficiency

\begin{tabular}{|c|c|c|}
\hline Variables & Parameter & SE \\
\hline Fertilizer $\left(X_{1}\right)$ & $\begin{array}{l}0.2016^{\star *} \\
(4.3660)\end{array}$ & 0.0462 \\
\hline Farm Size $\left(X_{2}\right)$ & $\begin{array}{l}0.3184 \\
(0.8724)\end{array}$ & 0.3650 \\
\hline Labour $\left(\mathrm{X}_{4}\right)$ & 0.0380 & 0.0536 \\
\hline Seed $\left(X_{4}\right)$ & $\begin{array}{l}(0.7094) \\
0.4745^{\star *} \\
(3.8095)\end{array}$ & 0.1246 \\
\hline Constant (K) & $\begin{array}{l}6.2367^{* *} \\
0.4072 \\
(15.3168)\end{array}$ & 0.4072 \\
\hline INEFFICIENCY I & & \\
\hline $\operatorname{Age}\left(d_{1}\right)$ & $\begin{array}{l}-2.3831 \\
(1.4326)\end{array}$ & 1.6635 \\
\hline Education $\left(\mathrm{d}_{2}\right)$ & $\begin{array}{l}0.0134 \\
(0.0708)\end{array}$ & 0.1894 \\
\hline Compliance $\left(\mathrm{d}_{3}\right)$ & $\begin{array}{l}0.3369 * * \\
(5.0442)\end{array}$ & 0.0668 \\
\hline Constant $\left(\mathrm{d}_{0}\right)$ & $\begin{array}{l}-20.9653^{* *} \\
(4.7325)\end{array}$ & 4.4301 \\
\hline
\end{tabular}

Diagnostic Statistics

\begin{tabular}{ll}
\hline Variables & RSPT \\
\hline ó $^{2}$ & $5.8473^{\star *}$ \\
Loglikelihood $\left(\mathrm{H}_{1}\right)$ & $(4.0008)$ \\
Loglikelihood $\left(\mathrm{H}_{0}\right)$ & -40.1066 \\
Mean Efficiency & -163.5091 \\
& 0.7518 \\
\hline
\end{tabular}

Figures in parenthesis are the $t$ - values.

${ }^{* *}=5 \%$ level of significance. 


\section{Estimated Equations}

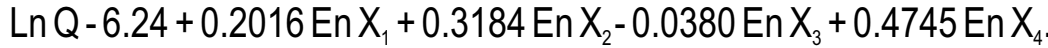

The sources of inefficiency in soybean production using rain-fed production technology are examined by looking at the estimated coefficients associated with inefficiency factors in Table 5 . These inefficiency factors are those relating to age, education and compliance. The coefficient of the dummy variable (age) is negative but not significant. That of education is positive but also not significant. This means that none of the two factors explain the variability in technical inefficiency in the use of rain-fed production technology for soybean production. However the coefficient of compliance $(0.3389)$ is positive and significant at $5 \%$. This indicates the inelastic nature of the variable. However its significance indicates that it explains in part, some of the variability in technical inefficiencies associated with the use of rain-fed upland production technology for the production of soybean. Increasing compliance will reduce technical inefficiency and raise output.

The mean technical efficiency for the sampled soybean farming households using rain-fed production technology is 0.7518 . The mean technical inefficiency is thus 0.2482 , (about $25 \%$ ). This is expected since the technical inefficiency effect in the estimated model is significant. This implies that the technical efficiencies of Soybean farming households in the study area are less than one. This means that they are not operating at their frontier of production.

The average technical inefficiency index of about 0.25 implies that their production is $75 \%$ of the technically feasible output, suggesting a potential to increase soybean production by $25 \%$ using rain-fed upland production technology without increasing the inputs use levels.

\section{CONCLUSION AND RECOMMENDATIONS}

This study focused on the economics of rain-fed Soybean production technology in Benue state of Nigeria. The data used were collected from 150 small-scale farming households using rainfed Soybean production technology in Benue state of Nigeria. The costs and gross margin associated with the use of the technology were determined. As the main thrust of the study, an analytical framework within which to evaluate the efficiency of the production technology was also developed. This was achieved via the use of Production Function Estimation to assess farming household output as affected by technology compliance.

Within the context of sustainable agricultural production practices, the development of appropriate technologies for use by peasant farmers forms the basis of technology development and dissemination. An incisive analysis of how crop production technologies affect farm cost and revenue can determine the full or part use or outright rejection of a technology or its components. Based on this premise, the results of this study indicate that the nature of farming in the study area is labour intensive, implying a conflict in the demand for labour for farming and other activities Under sole cropping which is prevalent in the study area, the conditions for the use of new improved production technologies are favourable and though the production technology was not fully complied with, the farming households had positive financial margins and favourable output-input 
ratios for the technology. This suggests that the use of the production technology meet the farming household's objectives of increased yield and can still be improved upon.

The study has clearly established that peasant farmers accept and are using the new soybean production technology but not at full compliance with the stipulated recommendations. In spite of this however, farmers recorded financial benefits arising from the use of the technology. It also confirmed the expectations of researchers-developers that the improved crop production technology though may not be $100 \%$ technically efficient, help farmers to increase their farm output and gross margin levels.

In light of the above, the present rain-fed soybean production technology needs to be revaluated for improvement and better efficiency. There is a dire need for modifications that fulfill low-cost input desires for the peasant farming systems.

\section{REFERENCES}

Dalton T.J. (1996). Soil degradation and Technical change in Southern Mali, Ph.D. dissertation, Purdue University IN4707-1145, USA.

Falusi A.O. (1995) "An Overview of Nigeria's Rural Economy: status, problems and potentials" NCEMA workshop on rural development held on $20-25^{\text {th }}$ August Statistics) 1999, Poverty and Agricultural Sector

Hildebrand, P.E. and J.T. Russell (1998) Adaptability Analysis lowa USA lowa State University Press.

Idachaba, F.S. (1995) Food for all Nigerians; is there Hope? Alumni Lecture, University of Ibadan, Nigeria $11^{\text {th }}$ August.

Iwe, M.O. (2003). The science and Technology of Soybean ROJOINT COMM. Services Ltd., Enugu, Nigeria, ISBN 978-32124-8-6.

Jondrow, J. Lovell, C.A Materov I.S and Schmidt, P (1982) "On the estimation of Technical inefficiency in the stochastic frontier production function model". J. Econometric 19:233-238.

Okali, C; Sumberg, J and Farrington, J. (1994) Farmer Participatory Research: Rhetoric and Reality London Intermediate Technology Publications.

Okoruwa, A.E, (1999) Soybean Processing and Utilization for Healthy Nutrition in West Africa IDRC/IITA Soybean Utilization Project Phase II (May 1994 - September 1999.)Final Report 